\title{
Understanding the biogeography of chemosynthetic ecosystems
}

\section{Comprendre la biogéographie des écosystèmes chémosynthétiques}

\author{
Paul A. Tyler ${ }^{\mathrm{a}, *}$, Christopher R. German ${ }^{\mathrm{a}}$, Eva Ramirez-Llodra ${ }^{\mathrm{a}}$, Cindy L. Van Dover ${ }^{\mathrm{b}}$

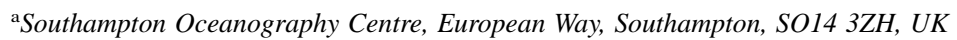 \\ ${ }^{\mathrm{b}}$ Department of Biology, College of William and Mary, Williamsburg, VA, 23187, USA
}

\begin{abstract}
ChEss is a recently-funded Census of marine life programme aimed at improving our knowledge of the biogeography of deepwater chemosynthetically driven ecosystems by promoting an international field phase of discovery and exploration. The main objectives are to assess and explain the diversity, distribution and abundance of hydrothermal vent and cold seep species. With the global mid-ocean ridge system extending $\sim 65000 \mathrm{~km}$, it is unlikely that its entire length would be examined in detail. The ChEss programme proposes to select a limited number of target areas chosen for the discovery of new vents and seeps. The intention is to identify the maximum scientific return that could be achieved from detailed investigation of the minimum number of sites at key locations. To narrow the field for exploration, a number of starting hypotheses and goals have been identified. A bio- and geo-referenced database for hydrothermal vent and cold seep species will be created. This database will be integrated with the Ocean Biogeographic Information System (OBIS). An international scientific committee will coordinate the programme, facilitate collaboration between participants, promote ship-time applications at national level and stimulate scientific innovation from a wider community.
\end{abstract}

(C) 2002 Ifremer/CNRS/IRD/Éditions scientifiques et médicales Elsevier SAS. All rights reserved.

\section{Résumé}

ChEss est un des programmes les plus récents du Recensement de la vie marine (CoML). Il doit accroître notre connaissance de la biogéographie des écosystèmes chémosynthétiques profonds en mettant en place une recherche internationale de terrain. L'objectif est de définir et d'expliquer la diversité, la distribution et l'abondance des espèces des évents hydrothermaux et des suintements froids. Avec un système de ride médio-océanique s'étendant sur 65000 kilomètres, une étude fine est hors de propos. Le programme ChEss propose de sélectionner un nombre limité d'aires-cibles choisies pour la découverte de nouveaux évents ou sources. L'objectif est de tirer un bénéfice maximum d'une étude détaillée d'un nombre réduit de sites choisis dans des positions-clefs. Pour focaliser le champ de recherche, quelques hypothèses et thèmes ont été identifiés. Une base de données biologiques et géologiques pour les espèces de ces aires sera créée ; elle sera intégrée à Obis (Ocean buiogeographic information system). Un Comité scientifique international coordonnera le programme, facilitera les coopérations, appuiera l'attribution de temps-bateau au niveau national et stimulera l'innovation scientifique pour une communauté élargie.

(C) 2002 Ifremer/CNRS/IRD/Éditions scientifiques et médicales Elsevier SAS. Tous droits réservés.

Keywords: Biogeography; Chemosynthetic ecosystems; Hydrothermal vent; Cold seep

Mots clés: Biogéographie; Écosystème chémosynthétique; Évent hydrothermal; Suintement froid

\section{Introduction}

\subsection{From the 'azoic zone' to deep-sea 'oases'}

The roots of our understanding of marine ecosystems lie in the interest of amateur naturalists of the late 18th and

\footnotetext{
* Corresponding author.

E-mail address: pat8@soc.soton.ac.uk (P.A. Tyler).
}

19th centuries. The development of deep-sea research as a science is associated with the development of new techniques of navigation, sampling and measuring, and follows the path of great oceanic expeditions.

Forbes was one of the first marine zoologists to explore deep waters between 1841 and 1842. Forbes developed his 'azoic theory' after dredging in the Aegean Sea and recovering fewer animals as the dredge hauls went deeper. He suggested that no life was present in the oceans below 600 
m. Forbes' 'azoic theory' was subsequently proved wrong, and there is added piquancy in that he missed discovery of the shallow-water chemosynthetic environments now known to occur in the Aegean Sea (Dando et al., 1995). The expeditions of the Lightning and Porcupine (late 1860s), and later, the circumglobal expedition of the Challenger (1872-1876), demonstrated that marine life could be found in the deep oceans as well as near shore (Murray and Hjort, 1912). The Galathea expedition (1950-1952) showed that marine life existed in even the deepest trenches in the world oceans.

In the 1960s-1970s, there was an important change in the approach of deep-sea biological research, with descriptive biology giving way to a more rigorous scientific method (Hessler and Sanders, 1967; Grassle and Sanders, 1973; Grassle, 1977). Improvements in sampling gear allowed the small-bodied fraction of the deep-sea species to be recovered, showing an increased diversity of deep-sea fauna (Hessler and Sanders, 1967). Concurrent with these discoveries was research in deep-sea technology, which led to the development of manned and unmanned submersibles. The ability to dive to the sea-bed to collect samples and to conduct manipulative experiments paved the way for arguably the greatest excitement in marine biology in the 20th century: the discovery of hydrothermal vents and their associated fauna.

By 1977, geologists had predicted that the heat-loss balance on earth could only occur if heat was lost at mid-ocean ridges by convective hydrothermal processes as well as by conductive processes (see Corliss et al., 1979). In 1977, an expedition to the Galapagos Rift in the East Pacific documented this convective process as a flux of lowtemperature vent fluids from basalt (Corliss et al., 1979). With this came the remarkable discovery that the hydrothermal vents were surrounded by a high-biomass community of invertebrates previously unknown to science.

Within months, it became apparent that the ecosystem associated with hydrothermal vents was driven by chemical energy (chemosynthesis) rather than by sunlight and vertical flux of organic matter (Jannasch and Wirsen, 1979; Karl et al., 1980), and that some metazoans contained chemosynthetic bacteria (Cavanaugh et al., 1981; Felbeck, 1981). This chemical energy is in the form of dissolved reduced gases, especially $\mathrm{H}_{2} \mathrm{~S}, \mathrm{H}_{2}$ and $\mathrm{CH}_{4}$. Hydrothermal vents were the first environment in which chemosynthetic primary production had been observed on such a large scale and where primary production from bacterial endosymbionts was recognised as being responsible for much of the metazoan biomass.

Following from the first discoveries, two major research tracks emerged. In one, the understanding of the biology of the organisms was the main aim (Childress et Fisher, 1992). In the other, the biogeographical context was the main driving force (Tunnicliffe, 1991; Tunnicliffe et al., 1998; Van Dover, 2000; Van Dover et al., 2001, 2002). The discovery of hydrothermal vents and, latterly, cold seeps has been one of the great interdisciplinary successes of oceanography for the last 25 years.

\subsection{Biogeography of known chemosynthetic environments}

\subsubsection{Hydrothermal vents}

The discovery of hydrothermal vents was first made along the Galapagos Rift in the East Pacific (Lonsdale, 1977; Corliss et al., 1979) (Table 1, Fig. 1). The biomass of these newly discovered vents was dominated by tubeworms (Riftia pachyptila), clams (Calyptogena magnifica), mussels (Bathymodiolus thermophilus) and a variety of gastropods and polychaetes. Within a very few years, vents had been discovered at $21^{\circ} \mathrm{N}$ (Spiess et al., 1980) and $13^{\circ} \mathrm{N}$ (Hekinian et al., 1983) on the East Pacific Rise (EPR). The EPR extends, along a roughly north-south axis, normal to the Galapagos Rift and separated from it by the 5000-mdeep Hess Deep. Hydrothermal sites along the EPR share invertebrate and fish species with hydrothermal vents of the Galapagos Rift. High-temperature vents $\left(350^{\circ} \mathrm{C}\right)$ and mineral chimneys were found along the EPR. The chimneys were colonised by alvinellid polychaetes, which have so far not been found along the Galapagos Rift because of an absence of habitat discovered at that time (Desbruyères and Laubier, 1982). Extending the discoveries further north along the EPR, vents were found in the Guaymas Basin site in the Gulf of California (Lonsdale and Becker, 1985). Although many of the species found in the Guaymas Basin were similar to those found on the EPR, the Guaymas Basin is a sediment-hosted vent site, resulting in only partial overlap of species lists among Guaymas and other EPR sites (Grassle, 1985). Although there are faunal variations among vents, the EPR and the Galapagos Rift are thought to form a single hydrothermal biogeographic province.

A second hydrothermal biogeographic province was identified with the discovery of hydrothermal vents in the Northeast Pacific in 1981 (Normark et al., 1982, 1983) (Table 1, Fig. 1). Initial discoveries were along the Juan de Fuca Ridge, and subsequently the Endeavour (1984) and Gorda (1988) Ridges (Table 1). Higher taxonomic levels were the same in the Northeast Pacific Ridge vents as at the EPR (e.g. vestimentiferans were present, but Ridgeia piscesae on the Northeast Pacific ridges replaces Riftia pachyptila, Tevnia jerichonana and Oasisia alvinae). There were, however, differences at the generic level between Northeast Pacific and EPR faunas, and there are small populations of Calyptogena spp. and Bathymodiolus spp. in the Northeast Pacific (for a detailed analysis, see Tunnicliffe et al., 1998).

In the western Pacific, hydrothermal vents were found in a variety of back-arc basins: the Lau Basin (1985), the Manus Basin (1986), the Marianas Trough and Fiji Basin (1987) and the Okinawa Trough (1988) (Table 1, Fig. 1). The communities of the West Pacific are heterogeneous, but at many of these sites, the dominant taxon was a gastropod that harboured chemosymbiotic bacteria, although mussels are abundant in places and tubeworms are found locally. 
Table 1

Discovery and biogeography of known hydrothermal vents deeper than $500 \mathrm{~m}$

\begin{tabular}{|c|c|c|c|c|c|}
\hline $\begin{array}{l}\text { Biogeographic } \\
\text { province }\end{array}$ & Site & Found & Depth (m) & Discovery & Faunal description \\
\hline \multirow[t]{7}{*}{ East Pacific } & Galapagos & 1977 & 2500 & Lonsdale (1977), Corliss et al. (1979) & Hessler and Smithey (1983) \\
\hline & $\mathrm{EPR} 21^{\circ} \mathrm{N}$ & 1979 & 2600 & Spiess et al. (1980) & $\begin{array}{l}\text { Hessler et al. (1985), Van Dover and Hessler } \\
\text { (1990) }\end{array}$ \\
\hline & EPR $13^{\circ} \mathrm{N}$ & 1981 & 2500 & Hekinian et al. (1983) & Desbruyères et al. (1982), Fustec et al. (1987) \\
\hline & Guaymas & 1980 & 2000 & Lonsdale et Becker (1985) & Grassle (1984), Grassle et al. (1985) \\
\hline & $9^{\circ} 50^{\prime} \mathrm{N}$ & 1989 & 2500 & Haymon et al. (1991) & Shank et al. (1998) \\
\hline & $17^{\circ} / 19^{\circ} \mathrm{S}$ & 1980 & $2600-2800$ & Renard et al. (1985) & \\
\hline & $>25^{\circ} \mathrm{S}$ & & & Unknown & Unknown \\
\hline \multirow{3}{*}{$\begin{array}{l}\text { Northeast } \\
\text { Pacific }\end{array}$} & Juan de Fuca & 1981 & 2200 & Normark et al. $(1982,1983)$ & Tunnicliffe et al. (1985) \\
\hline & Explorer & 1984 & 1850 & Tunnicliffe et al. (1986) & Tunnicliffe et al. (1986) \\
\hline & Gorda & 1988 & 2800 & Rona et al. (1990) & Van Dover et al. (1990) \\
\hline Mid-Pacific & Loihi & 1987 & $1000-1200$ & Karl et al. (1988) & Karl et al. (1989), Williams and Dobbs (1995) \\
\hline West Pacific & Manus & 1986 & 2190 & Both (1986) & Galkin (1992) \\
\hline \multirow{4}{*}{$\begin{array}{l}\text { Back-arc } \\
\text { basins }\end{array}$} & Marianas & 1987 & 3660 & Craig et al. (1987) & Hessler and Lonsdale (1991) \\
\hline & Fiji & 1987 & $2000-2700$ & Jollivet et al. (1989) & $\begin{array}{l}\text { Hashimoto and Jollivet (1989), Desbruyères et } \\
\text { al. (1994) }\end{array}$ \\
\hline & Lau & 1985 & $1707-1887$ & von Stackelberg et al. (1988) & Desbruyères et al. (1994) \\
\hline & Okinawa & 1988 & & Kimura et al. (1988) & Hashimoto et al. (1995) \\
\hline \multirow{8}{*}{$\begin{array}{l}\text { Mid-Atlantic } \\
\text { Ridge }\end{array}$} & Menez Gwen & 1994 & 850 & Fouquet et al. (1994) & Desbruyères et al. (2001) \\
\hline & Lucky Strike & 1992 & 1700 & Langmuir et al. (1993) & $\begin{array}{l}\text { Van Dover et al. (1996), Desbruyères et al. } \\
(2000,2001)\end{array}$ \\
\hline & Rainbow & 1997 & $2260-2350$ & Fouquet et al. (1997) & Desbruyères et al. $(2000,2001)$ \\
\hline & Broken Spur & 1993 & 2900 & Murton et al. (1993) & Murton et al. (1995), Van Dover (1995) \\
\hline & TAG & 1985 & 4000 & Rona et al. (1986) & Van Dover (1995), Gebruk et al. (1997) \\
\hline & Snake Pit & 1985 & 3480 & Kong et al. (1985) & Segonzac (1992), Sudarikov and Galkin (1995) \\
\hline & Logachev & 1994 & 3000 & Batuyev et al. (1994) & Gebruk et al. (2000) \\
\hline & South MAR & 2001 & $3000-3500$ & German et al. (2002) & Unknown \\
\hline East Scotia & & 1999 & 2600 & German et al. (2000) & Unknown \\
\hline \multicolumn{6}{|l|}{ Ridge } \\
\hline \multirow[t]{4}{*}{ Indian Ocean } & Central Ridge & 1986 & 3200 & Herzig and Pluger (1988) & Unknown \\
\hline & RTJ & 1995 & 2450 & Gamo et al. (1996) & Hashimoto et al. (2001), Van Dover et al. (2001) \\
\hline & SWIR & 1997 & $3100-4100$ & German et al. (1998b) & Unknown \\
\hline & SEIR & 1996 & $2500-2800$ & Scheirer et al. (1998) & Unknown \\
\hline \multirow[t]{2}{*}{ Arctic } & Gakkel & 2001 & $3500-4500$ & Edmonds et al. (in press) & Unknown \\
\hline & Knipovich & 2000 & 3200 & Connelly and German (2002) & \\
\hline
\end{tabular}

The back-arc basins of the western Pacific form a third major hydrothermal biogeographic province. Hydrothermal activity has also been identified on the Loihi Seamount off the southern tip of Big Island, Hawaii. This is the first recognised mid-ocean-plate hydrothermal vent, but none of the fauna present is endemic.

The mid-1980s saw the discovery of the first hydrothermal vents in the Atlantic (Rona et al., 1986). Over the following decade, a number of vent sites were discovered and explored from depths of $850 \mathrm{~m}$ at Menez Gwen to $\sim 3600 \mathrm{~m}$ at TAG (Table 1, Fig. 1). In contrast to the Pacific, no vestimentiferans or vesicomyid clams have been found in the Atlantic. The dominant chemosynthetic organisms are shrimp (Rimicaris exoculata) and bathymodiolid mussels. The mussels consist of two species (Bathymodiolus puteosepentis and B. azoricus) apparently separated by depth, although there is evidence of hybridisation (Maas et al., 1999). The faunal communities of the Mid-Atlantic Ridge (MAR) vents form a new hydrothermal biogeographic province. However, the known vents in the Atlantic are north of the equator. Recently, there has been evidence of at least one vent south of Ascension Island in the South Atlantic (Table 1). Further exploration of the MAR, both north and south of the known sites, will provide valuable information about the composition and distribution of the faunal groups along the ridge.

The most recent discoveries of vents have been along the Central Indian Ridge and at the Rodriguez Triple Junction (RTJ) (Table 1). At the RTJ sites Kairei and Edmond, shrimp species of Atlantic origin dominate in terms of biomass, whereas the species diversity is more representative of Pacific sites (Van Dover et al., 2001).

In the last few years, at least two plume signals have been observed along the East Scotia Ridge (Antarctic), whilst in the Arctic, evidence of hydrothermal activity has been found along the Knipovich Ridge and the Gakkel Ridge (German et al., 2000; Edmonds et al., 2001; Connelly and German, 2002) (Table 1). Discoveries of vents and potential vent sites are increasing continuously as more remote areas are explored. 


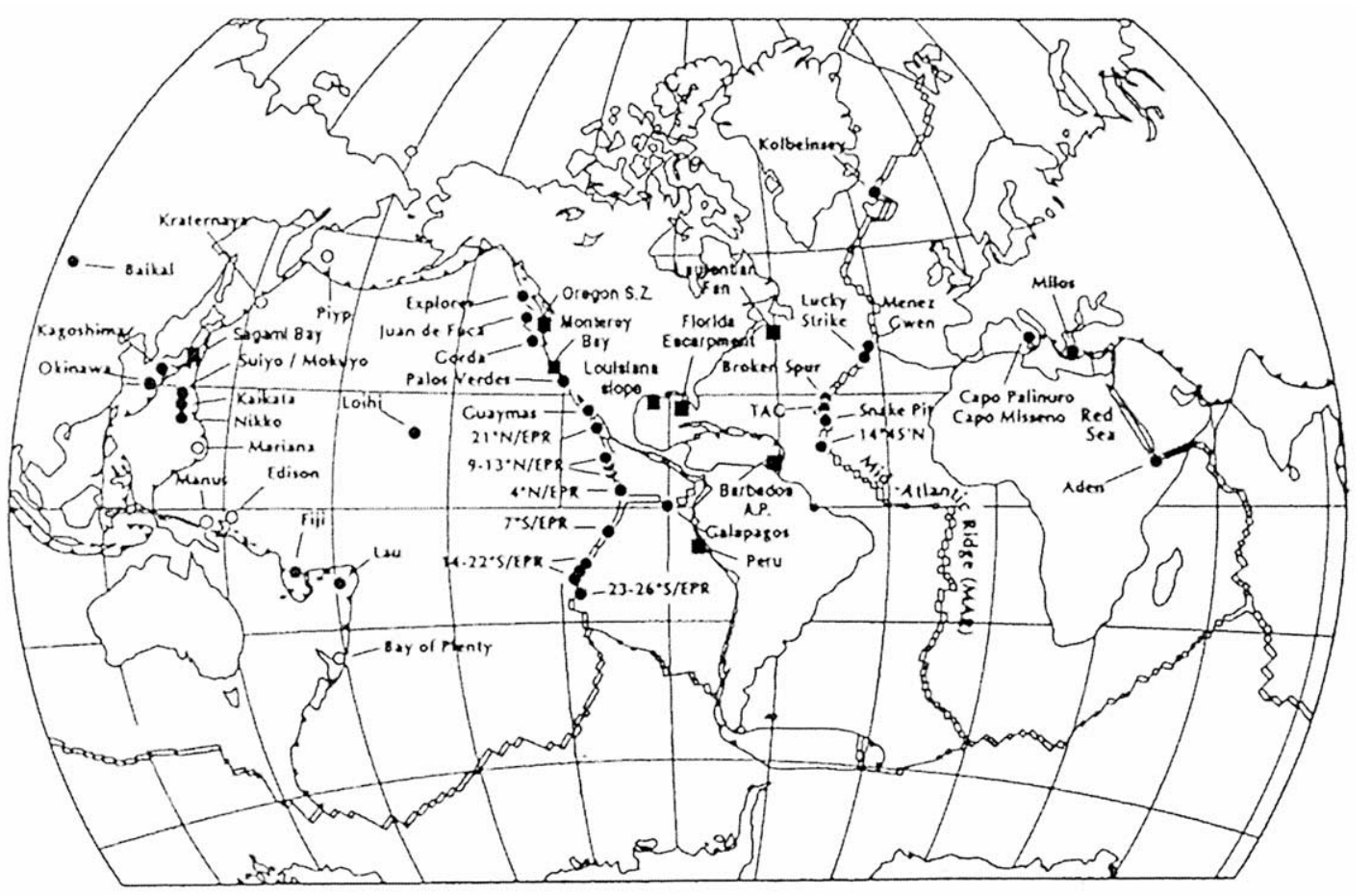

Fig. 1. Distribution of hydrothermal vents (circles) and cold seeps (squares) in the world ocean. Recent discoveries include Kairei and Edmonds vents (1), plumes along the SW Indian Ridge (2) and the Scotia Arc (3), and cold seeps off Angola (4) and the Hakon-Mosby Mud volcano (5).

\subsubsection{Cold seeps}

The interest in large chemosynthetic environments was strengthened by the discovery of a chemosynthetic-based fauna in the cold seeps at the base of the western Florida Escarpment in 1983 (Paull et al., 1984). At seeps, the dominant species were closely related to the higher taxa of hydrothermal vents. In less than 20 years, there has been an avalanche of discoveries of cold seeps from many parts of the world's oceans (Table 2, Fig. 1). Most of the cold seep sites are associated with the continental margin, both passive and active (Sibuet and Olu, 1998). The major passive margin sites include the Louisiana Slope and Florida Escarpment in the Gulf of Mexico, the Carolina Slope, Barents Sea, Gulf of Guinea and Angola Margin. The active margin cold seeps are mainly found around the Pacific Rim, associated with subduction zones, with the notable exception of the Barbados Accretionary Prism in the Atlantic (Table 2, Fig. 1) and the cold seeps in the eastern Mediterranean. Methane-rich fluids of biogenic and/or thermogenic origin are the main source of energy for these ecosystems. Sulphide is, however, produced in the sediments by sulphate reduction using methane, and is often more important than methane as an energy source for seep chemosynthetic communities (Paull et al., 1984; Barry et al., 1997). The most conspicuous fauna of cold seep ecosystems are large vesicomyid clams, mytilid mussels, vestimentiferan tubeworms and cladorhizid and hymedesmiid sponges. At high taxonomic levels, the faunal composition is similar to that found in the Pacific hydrothermal vents, but with significant differences in species composition, diversity and abundances (Sibuet and Olu, 1998).

Cold seep communities have also been recognised associated with whale falls (Bennett et al., 1994). When a whale dies and sinks to the deep-sea floor, the flesh soon disappears through the activity of scavenging invertebrates and fish. Oils, particularly in the vertebrae of the whale, then decompose, giving rise to a highly localised chemosynthetic community that will survive on the order of decades. An anomalous situation is represented by the wreck of the Francois Vieljeux. This coaster sank in $1200 \mathrm{~m}$ of water off the northwestern coast of Spain in 1991. The cargo was copper ingots, coffee beans and fruit. On recovery of some of the copper ingots, vestimentiferan tubeworms were brought to the surface (Dando et al., 1992). It is apparent that the coffee beans and fruit had decomposed to form a reducing environment that was colonised by larvae of vestimentiferans. This may not seem so surprising, except that the nearest known source of vestimentiferan larvae was in the Gulf of Mexico, and they were known to have a larval life of $<30 \mathrm{~d}$ (Young et al., 1996). This implied that there must be a source of larvae to colonise this wreck much closer than the Gulf of Mexico.

\section{The ChEss programme: what we want and need to know}

The main aim of the ChEss programme is to improve our knowledge of the biogeography of deepwater chemosyn- 
Table 2

Discovery and biogeography of known cold seeps greater than $500 \mathrm{~m}$ in depth

\begin{tabular}{|c|c|c|c|c|c|}
\hline $\begin{array}{l}\text { Biogeographic } \\
\text { province }\end{array}$ & Site & Found & Depth & Discovery & Faunal description \\
\hline \multirow{3}{*}{ Gulf of Mexico } & Florida Escarpment & 1983 & 3500 & Paull et al. (1984) & Paull et al. (1984), Hecker (1985) \\
\hline & Louisiana Slope & 1984 & $400-1000$ & Brooks et al. (1984) & Kennicutt et al. (1985), MacDonald et al. (1989) \\
\hline & Alimos Canyon & & 2200 & & Carney (1994) \\
\hline \multirow{9}{*}{ Atlantic } & Carolina Slope & 1994 & 2160 & Paull et al. (1995) & Paull et al. (1995) \\
\hline & Laurentian Fan & 1986 & 3850 & Mayer et al. (1988) & Mayer et al. (1988) \\
\hline & Barents Sea & 2000 & & & Gebruk et al. (in press) \\
\hline & S. Barbados AP & 1985 & $1000-2000$ & Faugères et al. (1987) & Jollivet et al. (1990) \\
\hline & N. Barbados AP & 1989 & $4700-5000$ & Le Pichon et al. (1990) & Olu et al. (1997) \\
\hline & Angola & & & & Unknown \\
\hline & Brazil & & & & Unknown \\
\hline & Gulf of Guinea & & $400-700$ & Cochonat et al. (1996) & Unknown \\
\hline & Francois Vieljeux & 1991 & 1250 & Dando et al. (1992) & Dando et al. (1992) \\
\hline Mediterranean & Eastern & 1993 & $1700-2000$ & Corselli and Brasso (1996) & Corselli and Brasso (1996) \\
\hline \multirow[t]{10}{*}{ East Pacific } & Aleutian Trench & 1994 & $3200-5900$ & Suess et al. (1998) & Suess et al. (1998) \\
\hline & Oregon AP & 1984 & $2000-2400$ & Suess et al. (1985) & Suess et al. (1985), Kulm et al. (1986a) \\
\hline & N. California & 1988 & $450-600$ & Kennicutt et al. (1989) & Kennicutt et al. (1989) \\
\hline & Monterey Bay & & $600-1000$ & Green et al. (1993) & Green et al. (1993) \\
\hline & Monterey Fan & 1988 & $3000-3600$ & Embley et al. (1990) & Embley et al. (1990) \\
\hline & San Clemente Fault & & 1800 & Lonsdale (1979) & Lonsdale (1979) \\
\hline & Sonora Margin & 1980 & 1600 & Lonsdale and Becker (1985) & Simoneit et al. (1990) \\
\hline & Costa Rica AP & 1994 & 3500 & Khan et al. (1994) & Undescribed \\
\hline & Peru Trench & 1991 & $2300-5100$ & Kulm et al. (1986b) & Fiala-Medioni et al. (1992), Olu et al. (1996) \\
\hline & Chile Trench & & 1400 & & Stuardo and Valdovinos (1988) \\
\hline \multirow[t]{5}{*}{ West Pacific } & Japan Trench & 1984 & $3800-6000$ & Laubier et al. (1986) & Cadet et al. (1987a,b), Sibuet et al. (1988) \\
\hline & Kurile Trench & 1985 & $3800-6000$ & Laubier et al. (1986) & Cadet et al. (1987b), Laubier et al. (1986) \\
\hline & Nankai Prism & 1985 & $2000-3800$ & Laubier et al. (1986) & $\begin{array}{l}\text { Juniper and Sibuet (1987), Ohta and Laubier (1987), } \\
\text { Sibuet et al. (1990) }\end{array}$ \\
\hline & Tenryu Canyon & 1985 & $3600-3850$ & Okutani and Metivier (1986) & Juniper and Sibuet (1987) \\
\hline & Sagami Bay & & $900-1200$ & Okutani and Egawa (1985) & $\begin{array}{l}\text { Hashimoto et al. (1988), Hashimoto and Jollivet } \\
\text { (1989) }\end{array}$ \\
\hline
\end{tabular}

thetically driven ecosystems by promoting an international 10 -year field phase of discovery and exploration. With the global mid-ocean ridge system being the longest linear structure in the oceans $(65000 \mathrm{~km})$, it is unlikely that we will ever be able to examine its entire length in detail. As a result, it is necessary to be selective in the areas chosen as targets for the discovery of hydrothermal vents. The geographic problem is even more acute for cold seep environments, as the sedimentary deep-sea floor covers over $50 \%$ of the surface of the earth. Accordingly, the intention is to identify the maximum scientific return that could be achieved from detailed investigation of a minimum number of new sites at key locations.

To narrow the field for exploration, we address a series of hypotheses based on our actual knowledge about the distribution of vent and seep species. Many of the hypotheses are site specific (Fig. 2) and include the following inter alia.

- Vent species along the Southeast Indian Ridge (SEIR) show increasing influence of Pacific faunas, whereas along the Southwest Indian Ridge (SWIR), Atlantic influences are greater.

- The vent fauna of the East Scotia Arc is influenced by its tectonic attachment to the Atlantic. Or alternatively, hydrographic inputs from the Pacific have the most profound effect on the species composition of Scotia Arc vents, with larvae from the southern EPR flowing through the Drake Passage, borne by the southernmost limb of the Antarctic Circumpolar Current (Meredith et al., 2001).

- Vents in the southern MAR may exhibit a fauna distinct from those north of the equator, with isolation driven by the offset of hundreds of kilometres created by the Chain and Romanche Fracture Zones.

- Recently discovered seep fauna off the coast of West Africa may be directly related to Gulf of Mexico fauna, owing to strong advection of southward-flowing Atlantic deep waters that cross from west to east at equatorial latitudes (Van Dover et al., 2002; Sibuet, personal communication).

- Fauna in vents in the Cayman Trough bear a close resemblance to those from the northern EPR, from which they have been tectonically isolated since closure of the Isthmus of Panama (deepwater closure at 10 $\mathrm{Ma}$; land bridge closure at $3 \mathrm{Ma}$ ).

- Vent fauna in vents along the Kolbeinsey, Mohns, Knipovich and Gakkel Ridges, north of Iceland, may be quite distinct from those along the MAR because the presence of the Iceland mantle hotspot has precluded pathways for deepwater migration between these basins since the opening of the North Atlantic Ocean (ca.60 $\mathrm{Ma})$.

- The Chile Rise (Southeast Pacific) is a vent-faunal 'dead end' towards the southeastern end. 


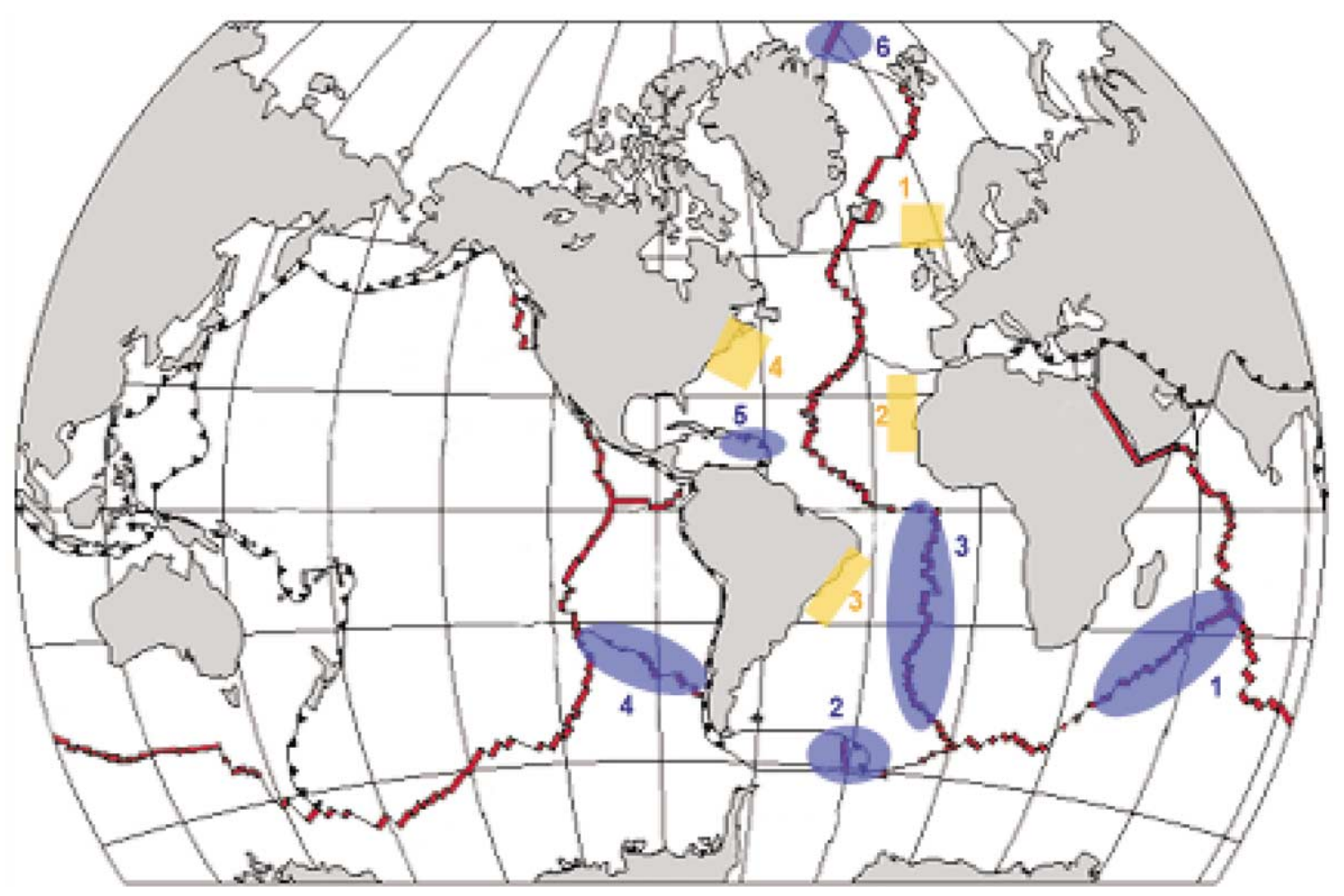

Fig. 2. Key geographic regions for exploration of vents (ellipses) and seeps (oblongs) under the ChEss programme. Vents: 1 - SW and Central Indian Ridge, 2 - Scotia Arc, 3 - Mid-Atlantic Ridge south of the equator, 4 - Chile Rise, 5 - Cayman Trough and 6 - High Arctic under the ice cap. Seeps: 1 - NE Atlantic, 2 - off NW Africa, 3 - Brazil and 4 - off east coast of US.

- Large transform faults and cross-mid-ocean-ridge landmasses form insurmountable barriers to dispersion.

To address these questions, we suggest a series of goals.

\subsection{Goal 1. To create a centralised database of species from chemosynthetic environments}

One of the objectives of the ChEss programme is to create a Web-based database for all known species from deepwater hydrothermal vents and cold seeps. The information of all vent and seep species that have been collected to date will be obtained by both literature research and visits to the main laboratories working with chemosynthetic communities. In the last 25 years, a great number of samples have been collected from deepwater chemosynthetic environments at great expense to national funding agencies. Observations, samples and data from these cruises have formed the base of our knowledge, but we believe there is still a wealth of collected video and species that are archived and have great value.

The vent and seep database will have two major entries, one biological and one geographical. At the biological level, the database will include the original description of the species, with line drawings and photos, the main biological aspects of the species and its distribution. At the geographical level, the different chemosynthetic sites will be defined, with the description of their vent or seep sites and a list of species composition. The geo-referenced and bio-referenced data will be interconnected, allowing the user to obtain the maximum information available, from the species level to the community and biogeographical levels. The ChEss database will be integrated with the Ocean Biogeographic Information System (OBIS).

\subsection{Goal 2. To initiate and establish a field programme to} locate potential vent sites by using and developing stateof-the-art technology

As a first-order goal, we should address the major geographical gaps in our knowledge of the distribution of chemosynthetic environments using some of the hypotheses recognised above to identify strategic sites for study. The field programme will have two main phases for each site: one of discovery (Goal 2) and one of exploration and biological analysis (Goal 3, see below).

The discovery phase will promote the development and further refinement of state-of-the-art technologies. These will combine in situ chemical sensors with co-registered geophysical equipment where appropriate, mounted on a combination of deep-towed and, in the future, autonomous vehicles. The standard procedure has been to use deeptowed optical sensors coupled with side-scan sonar imaging of the seafloor to provide first-order information about the abundance and likely geologic setting of high-temperature hydrothermal vents in previously uninvestigated areas. 

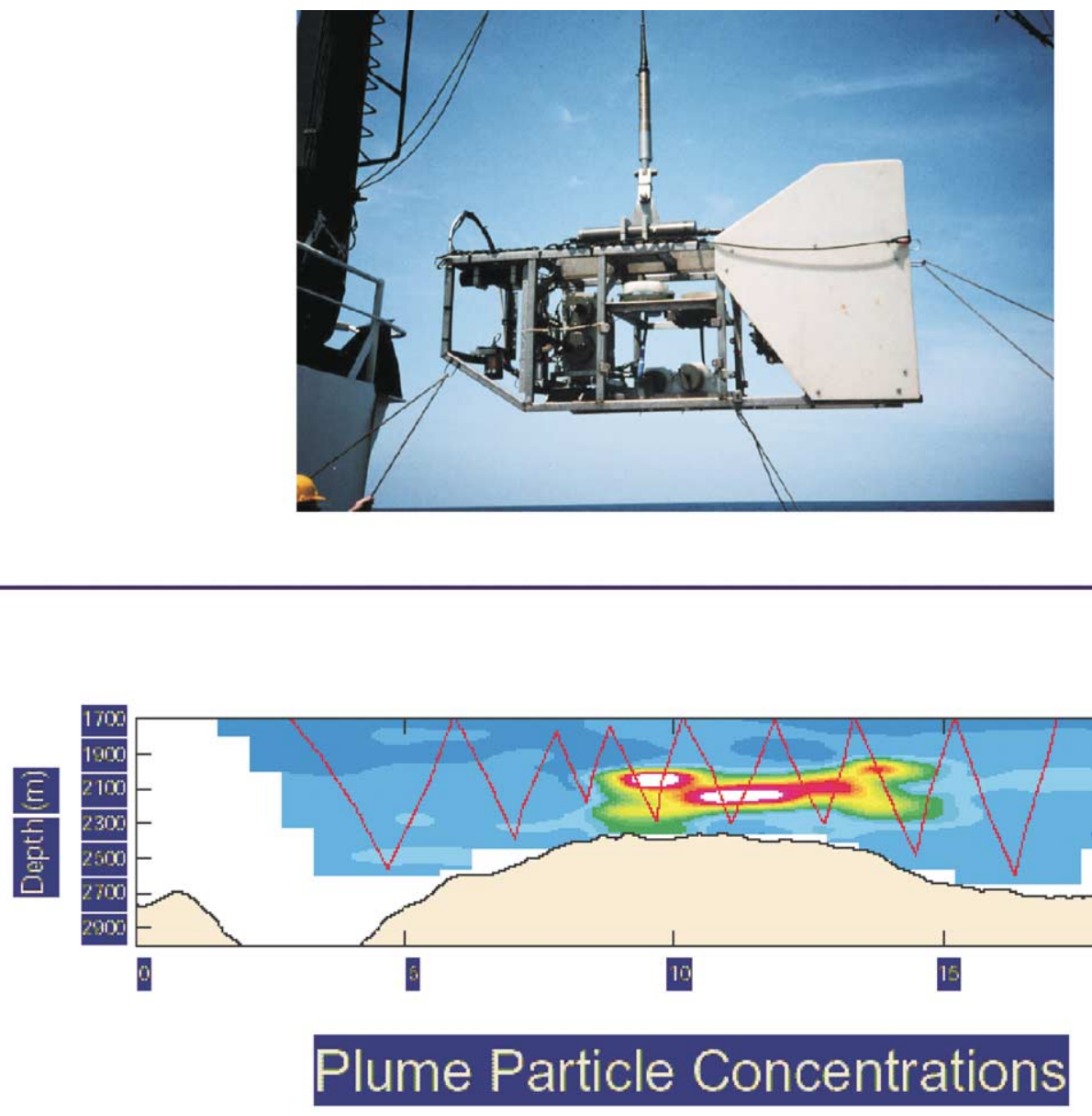

Fig. 3. (a) The 6000-m-rated BRIDGET deep-tow vehicle - a dedicated instrument for the detection, mapping and sampling of hydrothermal plumes (see Rudnicki et al., 1995). (b) Two-dimensional cross-section of hydrothermal plume particle concentrations in the Rainbow hydrothermal plume (36 ${ }^{\circ}$, Mid-Atlantic Ridge) as measured by a nephelometer mounted on the BRIDGET deep-tow vehicle (see German et al., 1998a).

Since 1994, six such deep-sea expeditions (2-3 weeks each) have successfully targeted between two and seven new sites of hydrothermal activity along 200-km sections of ridgecrest on the Knipovich Ridge (Arctic), the northern MAR, the East Scotia Ridge (Antarctic), the SWIR, the Central Indian Ridge and the southern EPR (German et al., 1996, 1998, 2000) (Fig. 2).

There are, however, limitations to the above approach. First, this rapid survey technique can only prove the existence of vents within target areas of a few kilometres (insufficiently precise for submersible/ROV dives). Second, there is no equivalent technique yet established for seep exploration on margins, although high-resolution seismic studies have proved effective in locating seep sites. Third, the use of deep-tow technology is increasingly impractical (weather, ice) at high latitudes. To solve these problems, it is an important component of ChEss to promote the development of emerging and novel technologies.

The use of dedicated hydrothermal deep-tow vehicles (e.g. ZAPS sled, USA; Bridget and Tobi, UK (Figs. 3 and
4)) has already proven effective at narrowing the focus of exploration from the regional scale to length scales of just a few hundred metres on the seafloor. Examples include the Broken Spur, Lucky Strike and Rainbow hydrothermal fields on the MAR which - following a nested survey strategy - were each found within just a few hours of seafloor exploration by submersible.

A next step is to adapt these same strategies to utilise novel sensors (e.g. in situ methane) to prospect specifically for cold seep environments on ocean margin settings using the same towed-vehicle approach. In parallel, it will be important to transfer these techniques onto autonomous underwater vehicles (AUVs) (Fig. 5). AUVs can be preprogrammed to conduct systematic, grided, flat-flying or undulating surveys to build up three-dimensional images of vent or seep effluents. The data obtained by the AUV (video, stills, swath bathymetry, side-scan sonar, concentration of specific elements) will be relayed back to the support ship either remotely or upon recovery - and the data interpreted to target subsequent remote ocean vehicle (ROV)/ submers- 

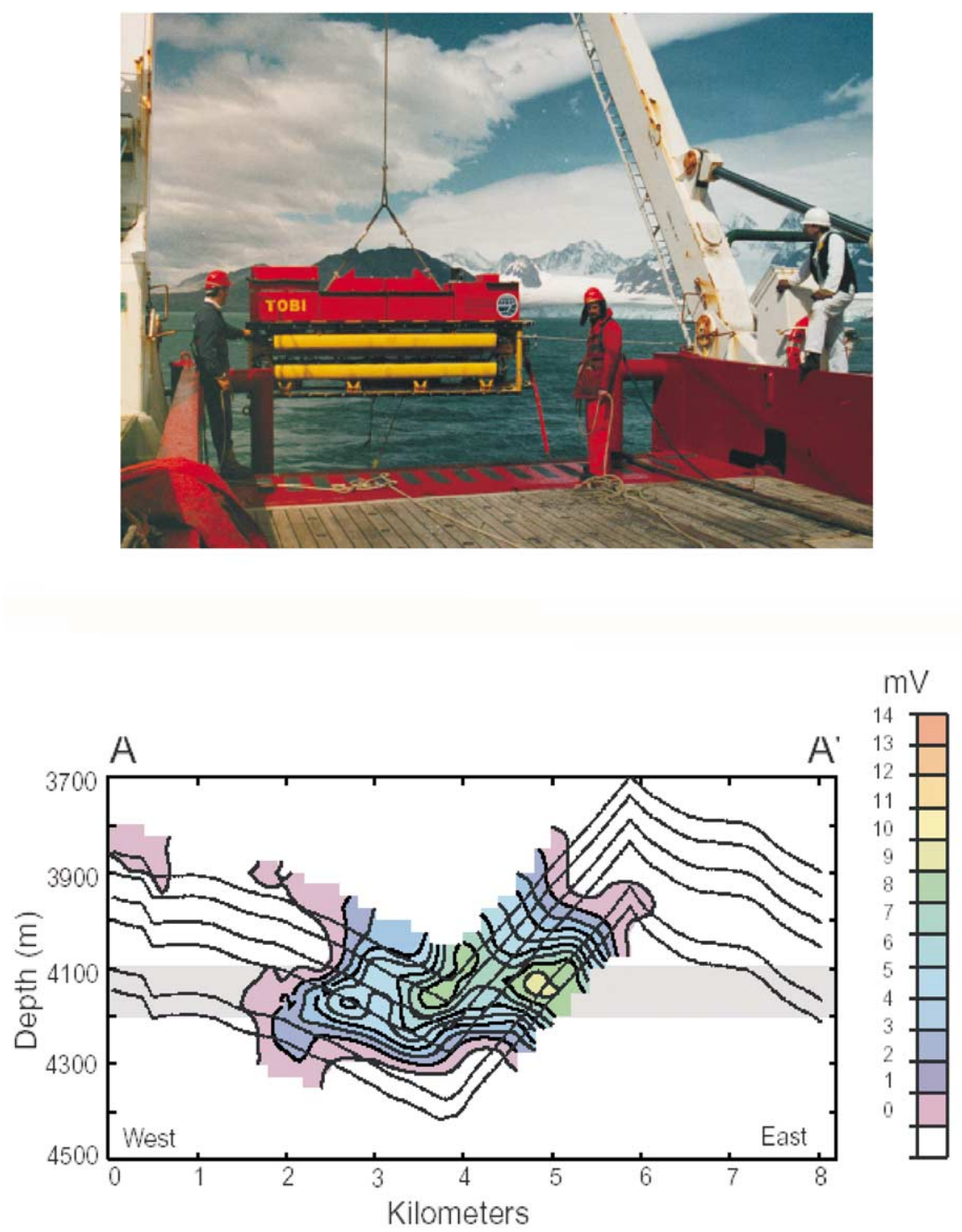

Fig. 4. (a) The TOBI deep-tow sidescan sonar vehicle with appended light-scattering sensor string, seen here during trials off Grytviken Harbour, South Georgia. (b) Two-dimensional cross-section of plume particle concentrations in a hydrothermal plume at $59^{\circ} \mathrm{E}$, SW Indian Ridge, as detected by an array of light-scattering sensors deployed above and below the TOBI vehicle (see German et al., 1998b).

ible dives. This will be of immediate benefit and improve exploration efficiencies at all latitudes and in all water depths (i.e. hydrothermal vents and cold seeps alike).

A greater, but quite tractable, challenge within this part of the ChEss programme will be to stimulate and promote the introduction of even greater autonomy into AUV systems (Fig. 5). Specifically, new control systems will need to be developed, and AUV mobility and endurance would need to be improved. The main objective would be to enable such vehicles to respond to in situ sensor data whilst on the seafloor and in real time, not just to detect the presence of chemical or other diagnostic seep and vent signals in the water column. Exploitation of spatial variability in these signals will be used to both locate and, ultimately, conduct preliminary 'automatic' investigations (e.g. first-order camera surveys) of new seafloor ecosystems.
The development and progress in AUV capacities and precision will improve the efficiency of ChEss to census vent and seep faunas and, potentially, other CoML activities throughout the world's oceans. In particular, such reliance on autonomous vehicles will be of greatest benefit as we extend our investigations into the hostile high-latitude environments of both the southern ocean and, most importantly, the permanently ice-covered Arctic Ocean.

\subsection{Goal 3. To find individual vents and seep sites and describe their fauna}

Exact location of vents invariably requires the use of either manned or unmanned submersible vehicles. With the exploration of vents targeted using the techniques in Goal 2, we believe the discovery of vents will become more 


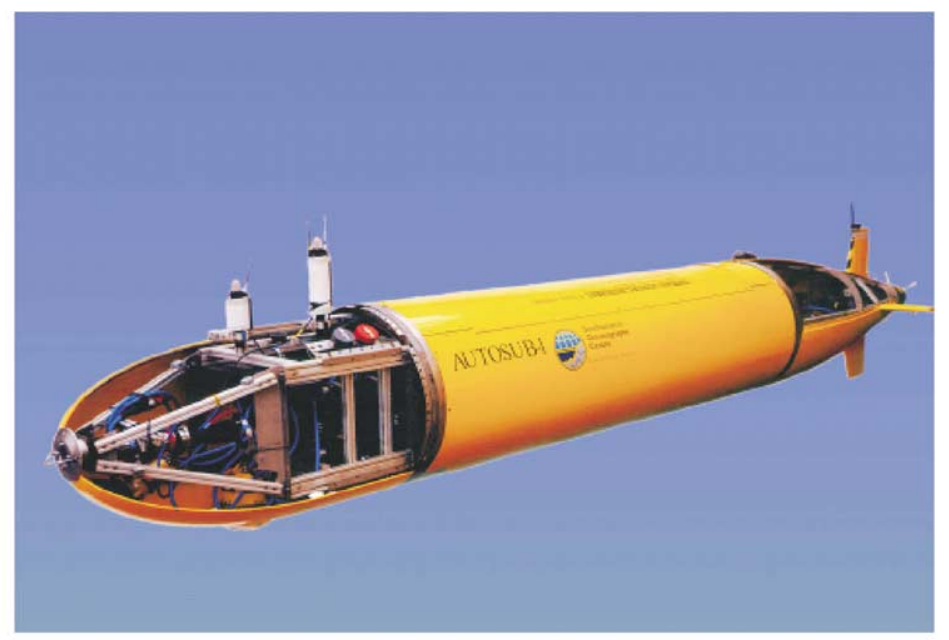

Time (minutes)

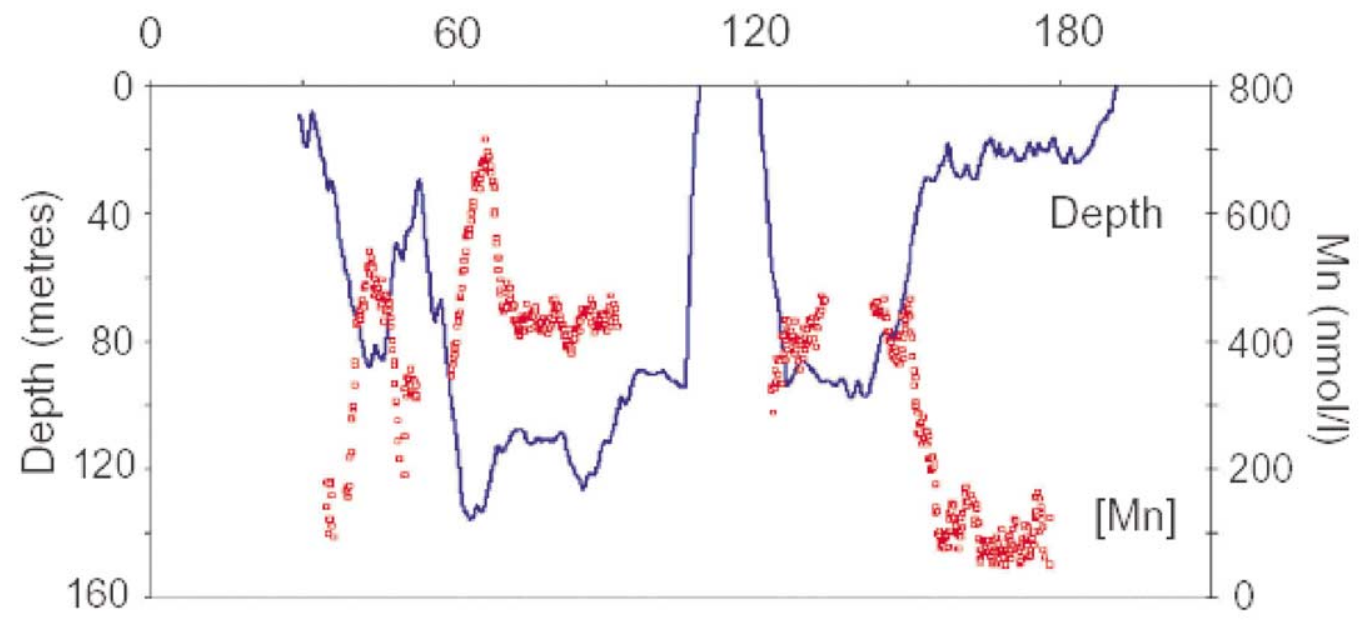

Fig. 5. (a) Schematic diagram of the AUTOSUB-I, prototype autonomous underwater vehicle of the Southampton Oceanography Centre (SOC). (b) Representative data from an in situ Mn sensor (red squares) and depth sensor (blue trace) deployed on AUTOSUB in Loch Etive, West Scotland. Loch Etive is a seasonally reducing fjord that, during episodes of low-oxygen conditions, exhibits high dissolved Mn concentrations in its more reducing deep waters. High dissolved Mn concentrations are also typical of deep-sea hydrothermal plumes (see Statham et al., in press).

efficient. Once a new vent or seep site is discovered, it will be necessary to standardise protocols for the imaging and sampling of the vent or seep environment. As the analysis of the processes driving an ecosystem has always followed hard on the heels of discovery, additional sampling protocols for ecosystem study, such as biomarker analyses (e.g. stable isotope and lipid analyses) and taxonomy (including molecular biology), need to be incorporated into the discovery programme. Such a nested and layered sampling strategy is critical for sites in remote oceanic locations, which may be visited very infrequently after initial discovery. A good example of such a protocol was the NSF-sponsored ROV programme to the remote Kairei and Edmond sites in the southern Indian Ocean (Van Dover et al., 2001).

\subsection{Goal 4. To use molecular methods for taxonomic and population biology studies}

In a study of the biogeography of chemosynthetic communities of the world's oceans, it is imperative that the taxonomic status of all the individuals be determined. Traditionally, this has been done by morphological methods. To date, molecular techniques are rapidly developing and are one of the most innovative aspects of deep-sea research. The molecular approach offers the possibility not only to identify cryptic species and discriminate between populations and metapopulations, but also to measure gene flow and to analyse the phylogeography, evolution and possible origin of the present genetic types. This, in parallel with the 
traditional morphological techniques for taxonomy, will significantly increase our understanding of the biogeography of chemosynthetic fauna.

The first level of application of molecular techniques is the identification of cryptic species. Traditional morphological methods cannot always discriminate between species found at vents and cold seeps. For example, molecular techniques resulted in the synonymy of the two 'species' of Ridgeia (based on morphology) found on the Juan de Fuca Ridge (Southward et al., 1996). In addition, cryptic species within the genus Bathymodiolus that proved difficult to distinguish morphologically have been identified using molecular techniques (Craddock et al., 1995a; Gustafson et al., 1998). The vesicomyid clams were assigned to two genera on morphological criteria, but subsequent molecular analysis has shown species of each genus to be closer to species of the other genus than to species in their own genus (Vrijenhoek et al., 1994; Peek et al., 1997). This taxonomic uncertainty still requires clarification.

The next level of molecular analysis is to discriminate between different populations of a single species. In Riftia pachyptila from the EPR, there appears to be some discrimination between samples from different vent sites, whereas in Bathymodiolus thermophilus, all samples along the EPR came from the same population. Any discrimination between populations is intimately concerned with dispersal of larvae (see Goal 5), and further molecular techniques can be used to measure gene flow and degree of isolation and endemism of vent and seep species.

Molecular methodologies are relatively well established in vent studies but have been used more sparingly in the study of organisms at cold seeps. Molecular techniques will allow us to look at not just biogeographical questions but also questions of evolution and adaptation.

\subsection{Goal 5. To understand the dispersal mechanisms that allow vent and seep species to maintain active sites and colonise new sites}

Reproductive variables such as fecundity, fertilisation success and larval type underpin dispersal in all marine organisms, and this is of special relevance in discrete habitats such as vents and seeps. However, only a few species described from hydrothermal vents and cold seeps have had their reproductive traits studied in detail (Tyler and Young, 1999).

The dispersal potential of larvae plays a major role in ecosystem and biogeographic studies. There has been considerable debate on the relative benefits of planktotrophy as opposed to lecithotrophy, but with no accepted consensus. Much of the evidence to date would suggest that the larval life of most invertebrates found at hydrothermal vents would be long enough for settlement sympatrically, but would not be long enough for advection to the next vent site along the ridge or an adjacent cold seep (see Chevaldonné et al., 1997, for a modelling approach; Marsh et al., 2001, for field data). Recent evidence suggests that the larvae of at least one species may arrest larval development until a vent site is found (Pradillon et al., 2001). In contrast, much of the molecular evidence suggests that gene flow is relatively high (Vrijenhoek, 1997; Tyler and Young, 1999), especially in some of the dominant invertebrate species in hydrothermal vents. Even brooding species such as the amphipod Ventiellia sulphuris have relatively high gene flow, suggesting that dispersal may also occur during both the juvenile and adult stage (France et al., 1992).

Larval type, larval development time and larval physiological requirements will determine dispersal capacities. Both laboratory and field experiments will determine the extent of larval life, but data on the life cycle of most vent and seep species are fragmentary at best. In vent species, studies on larval biology have been conducted on archaeogastropod larvae from EPR (Mullineaux et al., 1996), Bythograea thermydron (Epifanio et al., 1999) and Riftia pachyptila (Marsh et al., 2001; Thiébaut et al., 2002) and, to a slightly lesser extent, for the MAR bresiliid shrimp (Ramirez-Llodra et al., 2000; Tyler and Dixon, 2000).

Molecular methods can provide information on dispersal. Gene flow can be measured by a variety of methods (see Vrijenhoek, 1997). Gene flow has been measured in several vent species (Craddock et al., 1995b; Vrijenhoek et al., 1998), but most of the intraspecific comparisons made to date have been over relatively short geographic distances, although those for Riftia pachyptila and Bathymodiolus thermophilus cover some thousands of kilometres. By extending our knowledge of vent faunas into new regions, gene flow over much greater distances can be determined, providing clues to explain the overlap of species as found in the Indian Ocean (Van Dover et al., 2001).

In addition to the biological analysis, it is necessary to improve our understanding of the geographical barriers and physical forces affecting dispersive processes. Current meters, neutrally buoyant floats and acoustic dippler current profilers (ADCP) should be deployed in and around vent and seep areas in the future (German et al., 1998a; Marsh et al., 2001; Thurnherr et al., 2002).

\section{Conclusions: anticipated key deliverables and implementation of the Census of Marine Life}

The implementation of the ChEss programme will be at a number of levels. The programme will be organised and coordinated by an international scientific steering committee (SSC). The SSC will ensure collaboration between participants, stimulating national fund raising for the field phase and encouraging scientific innovation from a wider community. From the goals identified by ChEss, to address the objectives of the Census of Marine Life Programme, there follow a number of anticipated key deliverables:

1. Creation of a Web database for vent and seep species, including both archived and newly collected material. This 
will provide easy access to information on all data available on vent and seep species to date, providing a basis from which to determine the future direction of both exploration and analysis.

2. Optimisation of methodologies for the location of vent and seep ecosystems.

3. Coordination and integration of those national and international programmes that may result in increasing the resolution of the biogeographic model.

4. Discovery of new vent and seep sites and description of new species with specific physiological and ecological adaptations.

5. Description of standard protocols for sampling, preserving and archiving biological samples, including biochemical and molecular analyses.

6. Modelling the biogeography of chemosynthetic environments and explaining the species distribution through modelling of controlling factors.

The ChEss programme will increase our understanding of the biogeography of chemosynthetic environments, providing a detailed source of information on the diversity, abundance and distribution of deepwater vent and seep species at a global scale.

In addition, the results of the programme will provide the necessary scientific information to policy makers and stakeholders for the development of management and conservation options. In recent years, commercial activities in deep waters, such as deep-sea fishing, oil and gas exploration and polymetallic nodule exploitation, have rapidly expanded. These operations pose an increasing threat to deep-sea habitats in general and vent and seep ecosystems in particular. There is, however, an intensified concern from the scientific community, non-governmental organisations such as the World Wide Fund for Nature (WWF) and government departments to develop management and conservation options for deep-sea environments (Baker et al., 2001). One such example is the conservation initiative by the Government of the Azores, supported by WWF, aimed at the establishment of the first deep-sea Marine Protected Area (MPA) in the Northeast Atlantic. The Endeavour Segment of the Juan de Fuca Ridge is a Canadian Pilot MPA, and the hydrothermal vent fields Lucky Strike and Menez Gwen, situated in the Portuguese Exclusive Economic Zone at the MAR, are proposed as MPAs and shall be recognised as a natural heritage of mankind (Ricardo Santos, personal communication).

\section{Acknowledgements}

The authors would like to thank the Sloan Foundation for funding the ChEss programme as part of the Census of Marine Life initiative.

\section{References}

Baker, M.C., Bett, B.J., Billett, D.S.M., Rogers, A.D., 2001. The Status of Natural Resources on the High-Seas: An Environmental Perspective. WWW/WCPA/IUCN (Eds.), Gland, Switzerland..

Barry, J.P., Kochevar, R.E., Baxter, C.H., 1997. The influence of pore-water chemistry and physiology on the distribution of vesicomyid clams at cold seeps in Monterey Bay: implications for patterns of chemosynthetic community organization. Limnol. Oceanogr 42, 318-328.

Batuyev, B.N., Krotov, A.G., Markov, V.F., Gherkashev, G.A., Krasnov, S.G., Lisitsyn, Y.D., 1994. Massive sulfide deposits discovered at $14^{\circ} 45^{\prime} \mathrm{N}$, Mid-Atlantic Ridge. BRIDGE Newslett 6, 6-10.

Bennett, B.A., Smith, C.R., Glaser, B., Maybaum, H.L., 1994. Faunal community structure of a chemotrophic assemblage on whale bones in the deep northeast Pacific Ocean. Mar. Ecol. Progr. Ser. 108, 205-223.

Both, R.E.A., 1986. Hydrothermal chimneys and associated fauna in the Manus back-arc basin, Papua New Guinea. EOS Trans. Am. Geophys. Union 67, 489-490.

Brooks, J.M., Kennicutt II, M.C., Fay, R.R., McDonald, T.J., Sassen, R., 1984. Thermogenic gas hydrates in the Gulf of Mexico. Science 225, 409-411.

Cadet, J.P., Kobayashi, K., Aubouin, J., Boulegue, J., Deplus, C., Dubois, J., von Huene, R., Jolivet, L., Kanazawa, T., Kasahara, J., Koizumi, K., Lallemand, S., Nakamura, Y., Pautot, G., Suyehiro, K., Tani, S., Tokuyama, H., Yamazaki, T., 1987a. The Japan Trench and its juncture with the Kurile Trench: cruise results of the Kaiko project, Leg 3. Earth Planet. Sci. Lett. 83, 267-284.

Cadet, J.P., Kobayashi, K., Lallemand, S., Jolivet, L., Aubouin, J., Boulegue, J., Dubois, J., Hotta, H., Ishii, T., Kasahara, J., Konishi, K., Niitsuma, N., Shimamura, H., 1987b. Deep scientific dives in the Japan and Kurile Trenches. Earth Planet. Sci. Lett. 83, 313-328.

Carney, R.S., 1994. Consideration of the oasis analogy for chemosynthetic communities at Gulf of Mexico hydrocarbon vents. Geo-Mar. Lett. $14,149-159$.

Cavanaugh, C.M., Gardiner, S.L., Jones, M.L., Jannasch, H.W., Waterbury, J.B., 1981. Prokaryotic cells in hydrothermal vent tube worm Riftia pachyptila Jones: possible chemoautotrophic symbionts. Science 213, 340-342.

Chevaldonné, P., Jollivet, D., Vangriesheim, A., Desbruyères, D., 1997. Hydrothermal-vent alvinellid polychaete dispersal in the eastern Pacific. 1. Influence of vent site distribution, bottom currents, and biological patterns. Limnol. Oceanogr. 421, 67-80.

Childress, J.J., Fisher, C.R., 1992. The biology of hydrothermal vent animals: physiology, biochemistry, and autotrophic symbioses. Oceanogr. Mar. Biol. Annu. Rev. 30, 337-441.

Cochonat, P., Bourillet, J.F., Quemeneur, P., Colliat, J.L., 1996. Deepwater surveys reveal seafloor instabilities on continental slope of the Gulf of Guinea. Applied Geoscience Conference, Warwick, The Geological Society.

Connelly, D.P., German, C.R., 2002. Total dissolvable manganese anomalies over the Knipovich Ridge: evidence for hydrothermal activity. EOS Trans. Am. Geophys. Union 83, OS205-206.

Corliss, J.B., Dymond, J., Gordon, L.I., Edmond, J.M., von Herzen, R.P., Ballard, R.D., Green, K., Williams, D., Bainbridge, A., Crane, K., Andel, T.H., 1979. Submarine thermal springs on the Galapagos Rift. Science 203, 1073-1083.

Corselli, C., Brasso, D., 1996. First evidence of benthic communities based on chemosynthesis on the Mediterranean Ridge Eastern Mediterranean. Mar. Geol. 132, 227-239.

Craddock, C., Hoch, W.R., Gustafson, R.G., Lutz, R.A., Hashimoto, J., Vrijenhoek, R.C., 1995a. Evolutionary relationships among deep-sea mytilids Bivalvia: Mytilidae from hydrothermal vents and cold-water methane/sulfide seeps. Mar. Biol. 121, 477-485. 
Craddock, C., Hoeh, W.R., Lutz, R.A., Vrijenhoek, R.C., 1995b. Extensive gene flow among mytilid Bathymodiolus thermophilus populations from hydrothermal vents of the eastern Pacific. Mar. Biol. 124, 137-146.

Craig, H., Hobibe, Y., Fareley, K.A., Welhan, J.A., Kim, K.-R., Hey, R.H., 1987. Hydrothermal vents in the Mariana Trough: results of the first Alvin dives. EOS Trans. Am. Geophys. Union 68, 1531.

Dando, P., Hughes, J.A., Thiermann, F., 1995. Peliminary observations on biological communities at shallow hydrothermal vents in the Aegean Sea. In: Parson, L.M., Walker, C.L., Dixon, D.R. (Eds.). Hydrothermal Vents and Processes, Geological Society of London, pp. 303-317.

Dando, P.R., Southward, A.J., Southward, E.C., Dixon, D.R., Crawford, A., Crawford, M., 1992. Shipwrecked tube worms. Nature 356, 667.

Desbruyères, D., Laubier, L., 1982. Paralvinella grasslei, new genus, new species of Alvinellidae Polychaeta: Ampharetidae from the Galapagos Rift geothermal vents. Proc. Biol. Soc. Wash. 95, 484-494.

Desbruyères, D., Crassous, P., Grassle, J., Khripounoff, A., Reyss, D., Rio, M., Van Praet, M., 1982. Données écologiques sur un nouveau site d'hydrothermalisme actif de la ride du Pacific oriental. C. R. Acad. Sci. Paris Ser. III 295, 489-494.

Desbruyères, D., Alayse-Danet, A.M., Ohta, S., 1994. Deep-sea hydrothermal communities in south-western Pacific back-arc basins the North Fiji and Lau Basins: composition, microdistribution and food web. Mar. Geol. 116, 227-242.

Desbruyères, D., Almeida, A., Biscoito, M., Comtet, T., Khripounoff, A., Le Bris, N., Sarradin, P.M., Segonzac, M., 2000. A review of the distribution of hydrothermal vent communities along the northern Mid-Atlantic Ridge: dispersal vs. environmental controls. Hydrobiologia 440, 201-216.

Desbruyères, D., Biscoito, M., Caprais, J.C., Colaco, A., Comtet, T., Crassous, P., Fouquet, Y., Khripounoff, A., Le Bris, N., Olu, K., Riso, R., Sarradin, P.M., Segonzac, M., Vangriesheim, A., 2001. Variations in deep-sea hydrothermal vent communities on the MidAtlantic Ridge near the Azores plateau. Deep-Sea Res. 48, 1325-1346.

Edmonds, H.N., Michael, P.J., Baker, E.T., Connelly, D.P., Snow, J.E., Langmvir, C.M., Dick, M.J.B., German, C.R., Graham, D.W. Abundant hydrothermal venting along the ultra-slow spreading Gakkel Ridge, Arctic Ocean. Nature, in press.

Embley, R.W., Eittreim, S.L., McHugh, C.H., Normark, W.R., Rau, G.H., Hecker, B., DeBevoise, A.E., Greene, H.G., Ryan, W.B.F., et al., 1990. Geological setting of chemosynthetic communities in the Monterey Fan Valley system. Deep-Sea Res. 37, 1651-1667.

Epifanio, C.E., Perovich, G., Dittel, A.I., Cary, S.C., 1999. Development and behavior of megalopa larvae and juveniles of the hydrothermal vent crab Bythograea thermydron. Mar. Ecol. Progr. Ser. 185, $147-154$.

Faugères, J.C., Desbruyères, D., Gonthier, E., Griboulard, R., Poutiers, J., de Resseguier, A., Vernette, G., 1987. Temoins sedimentologiques et biologiques de l'activité téctonique actuelle du prisme d'accrétion de la Barbade. C. R. Acad. Sci. Paris Ser. II 305, 115-119.

Felbeck, H., 1981. Chemoautotrophic potential of the hydrothermal vent tubeworm Riftia pachyptila Jones (Vestimentifera). Science 213, 336-338.

Fiala-Medioni, A., Sibuet, M., Segonzac, M., Bourgois, J., cruise participants, 1992. Biological communities associated with cold vents in the Peru Trench Abstract. EOS Trans. Am. Geophys. Union 73, 153.

Fouquet, Y., Charlou, J.-L., Costa, I., Donval, J.-P., Radford-Knoery, J., Pelle, H., Ondreas, H., Lourenco, N., Segonzac, M., Tivey, M.K., 1994. A detailed study of the Lucky Strike hydrothermal site discovery of a new hydrothermal site: Menez Gwen; preliminary results of the DIVA1 cruise [5-29 May 1994]. InterRidge News 3, 14-17.
Fouquet, Y., German, C., Parson others, L., 1997. Discovery and first submersible investigations on the Rainbow hydrothermal field on the MAR $36^{\circ} 14^{\prime}$ N. EOS Trans. Am. Geophys. Union 78 (Suppl.), F832.

France, S.C., Hessler, R.R., Vrijenhoek, R.C., 1992. Genetic differentiation between spatially-disjunct populations of the deep-sea hydrothermal vent-endemic amphipod Ventiella sulfuris. Mar. Biol. 114, 551-559.

Fustec, A., Desbruyères, D., Juniper, S.K., 1987. Deep-sea hydrothermal vent communities at $13^{\circ} \mathrm{N}$ on the East Pacific Rise: microdistribution and temporal variation. Biol. Oceanogr. 4, 121-164.

Galkin, S.V., 1992. The benthic fauna of hydrothermal vents in the Manus Basin. Oceanology 32, 768-774.

Gamo, T., Nakayama, E., Shitashima, K., Isshiki, K., Obata, H., Okamura, K., Kanayama, S., Oomori, T., Koizuma, T., Matumoto, S., Hasumoto, H., 1996. Hydrothermal plumes at the Rodriguez triple junction. Indian Ridge. Earth Planet. Sci. Lett. 142, 261-270.

Gebruk, A.V., Galkin, S.V., Vereshchaka, A.L., Moskalev, L.I., Southward, A.J., 1997. Ecology and biogeography of the hydrothermal vent fauna of the Mid-Atlantic Ridge. Adv. Mar. Biol. 32, 93-144.

Gebruk, A.V., Chevaldonné, P., Shank, T., Lutz, R.A., Vrijenhoeck, R.C., 2000. Deep-sea hydrothermal vent communities of the Logatchev area $14^{\circ} 45^{\prime} \mathrm{N}$ Mid-Atlantic Ridge: diverse biotopes and high biomass. J. Mar. Biol. Assoc. UK 803, 383-393.

German, C.R., Klinkhammer, G.P., Rudnicki, M.D., 1996. The Rainbow hydrothermal plume $36^{\circ} 15^{\prime} \mathrm{N}$, MAR. Mar. Geophys. Res. Lett. 23, 2979-2982.

German, C.R., Richards, K.J., Rudnicki, M.D., Lam, M.M., Charlou, J.L., 1998a. Topographic control of a dispersing hydrothermal plume. Earth Planet. Sci. Lett. 156, 267-273.

German, C.R., Baker, E.T., Mevel, C., Tamaki, K., The FUJI Science team, 1998b. Hydrothermal activity along the southwest Indian Ridge. Nature 395, 490-493.

German, C.R., Livermore, R.A., Baker, E.T., Bruguier, N.I., Connelly, D.P., Cunningham, A.P., Morris, P., Rouse, I.P., Statham, P.J., Tyler, P.A., 2000. Hydrothermal plumes above the East Scotia Ridge: an isolated high-latitude back-arc spreading centre. Earth Planet. Sci. Lett. 184, 241-250.

German, C.R., Connelly, D.P., Evans, A.J., Parson, L.M., 2002. Hydrothermal activity on the Southern Mid- Atlantic Ridge. Eos. Trans. A GU 83 (Suppl.), Abstract V61B-1361.

Grassle, J.F., 1984. Animals in the soft sediments near the hydrothermal vents. Oceanus 27, 63-66.

Grassle, J.P., 1985. Genetic differentiation in populations of hydrothermal vent mussels Bathymodiolus thermophilis from the Galapagos Rift and at $13^{\circ} \mathrm{N}$ on the East Pacific Rise. Bull. Biol. Soc. Wash 6, $429-442$.

Grassle, J.F., Sanders, H.L., 1973. Life histories and the role of disturbance. Deep-Sea Res 20, 643-659.

Grassle, J.F., Brown-Leger, L.S., Morse-Porteous, L., Petrecca, R., Williams, I., 1985. Deep-sea fauna in the vicinity of hydrothermal vents. Bull. Biol. Soc. Wash. 6, 443-452.

Green, H.G., Orange, D., Barry, J.P., 1993. Geological diversity of cold seep communities, Monterey Bay region, Central California, U.S.A. Am. Geophys. Union 74, 578.

Gustafson, R.G., Turner, R.D., Lutz, R.A., Vrijenhoek, R.C., 1998. A new genus and five new species of mussels Bivalvia, Mytilidae from deep-sea sulfide/hydrocarbon seeps in the Gulf of Mexico. Malacologia 40, 63-112.

Hashimoto, J., Jollivet, D., 1989. The Hydrothermal Vent Communities in the North Fiji Basin: Results of Japan-France Cooperative Research On Board Kaiyo 88. UMI/La Mer, Tokyo 271-2 pp. 62-71.

Hashimoto, J., Matsuzawa, S., Hotta, H., 1988. Searching for biological communities at the Okinoyama bank site, the Sagami Bay. JAMSTECT, Deep-Sea Res 4, 177-188. 
Hashimoto, J., Fujikura, K., Tanishima, M., Fujiwara, Y., Ohta, S., Kojima, S., Yieh, S.-M., 1995. Observations of a deep-sea biological community co-dominated by lucinid bivalve, Lucinoma spectabilis Yokoyama, 1920 and vestimentiferans at the Kanesu-no-Se Bank, Enshu-Nada, central Japan. JAMSTEC, Deep-Sea Res, 211-217.

Hashimoto, others, J., 2001. Hydrothermal vents and associated biological communities in the Indian Ocean. InterRidge News 10, 21-22.

Haymon, R.M., Fornari, D.J., Edwards, M.H., Carbotte, S., Wright, D., MacDonald, K.C., 1991. Hydrothermal vent distribution along the East Pacific Rise crest $9^{\circ}$ 09'-54' $\mathrm{N}$ and its relationship to magmatic and tectonic processes on fast-spreading mid-ocean ridges. Earth Planet. Sci. Lett. 104, 513-534.

Hecker, B., 1985. Fauna from a cold sulfur-seep in the Gulf of Mexico, comparison with hydrothermal vent communities and evolutionary implications. Bull. Biol. Soc. Wash. 6, 465-473.

Hekinian, R., Fevrier, M., Avedick, F., Cambon, P., Charlou, J.L., Needham, H., Raillard, J., Boulegue, J., Merlivat, L., Moinet, A., Manganini, S., Lange, J., 1983. East Pacific Rise near $13^{\circ} \mathrm{N}$ : geology of new hydrothermal fields. Science 219, 1321-1324.

Herzig, P.M., Pluger, W.L., 1988. Exploration for hydrothermal activity near the Rodriguez Triple Junction, Indian Ocean. Can. Mineralog. 26, 721-736.

Hessler, R.R., Lonsdale, P.F., 1991. Biogeography of Mariana Trough hydrothermal vent communities. Deep-Sea Res. 38, 185-199.

Hessler, R.R., Sanders, H.L., 1967. Faunal diversity in the deep-sea. Deep-Sea Res. 14, 65-78.

Hessler, R.R., Smithey, W.M., 1983. The distribution and community structure of megafauna at the Galapagos Rift hydrothermal vents. In: Rona, P.A., Bostrom, K., Laubier, L., Smith, K.L. (Eds.), Hydrothermal Processes at Seafloor Spreading Centres. Plenum, New York.

Hessler, R.R., Smithey Jr, W.M., Keller, C.M., 1985. Spatial and temporal variation of giant clam, tube worms and mussels at deep-sea hydrothermal vents. Bull. Biol. Soc. Wash. 6, 411-428.

Jannasch, H.W., Wirsen, C.O., 1979. Chemosynthetic primary production at East Pacific seafloor spreading centers. Bioscience 29, 592-598.

Jollivet, D., Hashimoto, J., Auzende, J.M., Honza, E., Ruellan, E., Dutt, S., Iwabuchi, Y., Jarvis, P., Joshima, M., et al., 1989. First observations of faunal assemblages associated with hydrothermalism in the NorthFiji back-arc basin. C. R. Acad. Sci. Paris Ser. III 309, 301-308.

Jollivet, D., Faugères, J.C., Griboulard, R., Desbruyères, D., Blanc, G., 1990. Composition and spatial organization of a cold seep community on the South Barbados accretionary prism: tectonic, geochemical and sedimentary context. Progr. Oceanogr. 24, 25-45.

Juniper, S.K., Sibuet, M., 1987. Cold seep benthic communities in Japan subduction zones: spatial organization, trophic strategies and evidence for temporal evolution. Mar. Ecol. Progr. Ser. 40, 115-126.

Karl, D.M., Wirsen, C.O., Jannasch, H.W., 1980. Deep-sea primary production at Galapagos hydrothermal vents. Science 207, 1345-1347.

Karl, D.M., McMurty, G.M., Malahoff, A., Garcia, M.O., 1988. Loihi Seamount: a mid-plate volcano with a distinctive hydrothermal system. Nature 335, 532-535.

Karl, D.M., Brittain, A.M., Tilbrook, B.D., 1989. Hydrothermal and microbial processes at Loihi Seamount, a mid-plate hot-spot volcano. Deep-Sea Res. 36A, 1655-1673.

Kennicutt II, M.C., Brooks, J.M., Bidigare, R.R., Fay, R.R., Wade, T.L., McDonald, T.J., 1985. Vent-type taxa in a hydrocarbon seep region on the Louisiana slope. Nature London 317, 351-353.

Kennicutt II, M.C., Brooks, J.M., Bidigare, R.R., McDonald, S.J., Adkison, D.L., Macko, S.A., 1989. An upper slope cold seep community: Northern California. Limnol. Oceanogr. 34, 635-640.

Khan, L.M., Orange, D., McAdoo, D., Ferioli, L., McIntoshc, K.D., Abbott, K.D., Screaton, E., Protti, M., Galewsky, M., Langseth, E., You, C.F., Gieskes, J., 1994. Evidence of fluid venting from the Costa Rica accretionary prism. EOS Trans. Am. Geophys. Union Spring Meet (Suppl.), 324.
Kimura, M., Uyeda, S., Kato, Y., Tanaka, T., Yamano, M., Gamo, S., Sakai, H., Kato, S., Izawa, E., Oomori, T., 1988. Active hydrothermal mounds in the Okinawa Trough back arc basin, Japan. Tectonophysics 145, 319-324.

Kong, L., Ryan, W.B.F., Mayer, L.A., Detrick, R.S., Fox, P.J., Manchester, K., 1985. Bare-rock drill sties, ODP Legs 106 and 109: evidence for hydrothermal activity at $23^{\circ} \mathrm{N}$ in the Mid.Atlantic Ridge. EOS Trans. Am. Geophys. Union 66, 106.

Kulm, L., Suess, E., Moore, J.C., Carson, B., Lewis, B.T., Ritger, S.D., Kadko, D.C., Thornburgh, T.M., Embley, R.W., Rugh, W.D., Massoth, G.J., Langseth, M.G., Cochrane, G.R., Scamman, R.L., 1986a. Oregon subduction zone: venting fauna and carbonates. Science 231, 561-566.

Kulm, L.D., Suess, E., Thornburgh, T.M., Embley, R.W., Hussong, D.M., Resig, J.M., 1986b. Fluid venting processes and their relation to tectonic styles in subduction zones of the eastern Pacific. International KAIKO Conference on Subduction Zones. Shimizu, Tokyo.

Langmuir, C., Fornari, D., et al., 1993. Geological setting and characteristics of the Lucky Strike Vent Field at $37^{\circ} 17^{\prime} \mathrm{N}$ on the Mid-Atlantic Ridge. EOS Trans. Am. Geophys. Union 74, 99.

Laubier, L., Ohta, S., Sibuet, M., 1986. Decouverte de communautes animales profondes durant la campagne franco-japonaise KAIKO de plongees dans les fosses de subduction autour du Japon. C. R. Acad. Sci. Paris Ser. III 303, 25-29.

Le Pichon, X., Foucher, J.P., Boulegue, J., Henry, P., Lallemand, S., Benedetti, M., Avedick, F., Mariotti, A., 1990. Mud volcano field seaward of the Barbados accretionary complex: a submersible survey. J. Geophys. Res. 95, 8931-8943.

Lonsdale, P., 1977. Clustering of suspension-feeding macrobenthos near abyssal hydrothermal vents at oceanic spreading centres. Deep-Sea Res. 24, 857-863.

Lonsdale, P., 1979. A deep-sea hydrothermal site on a strike-slip fault. Nature 281, 531-534.

Lonsdale, P., Becker, K.P., 1985. Hydrothermal plumes, hot springs and conductive heat flow in the Southern Trough of Guaymas Basin. Earth Planet. Sci. Lett. 73, 211-225.

Maas, P.A.Y., O’Mullan, G.D., Lutz, R.A., Vrijenhoek, R.C., 1999. Genetic and morphometric characterization of mussels Bivalvia: Mytilidae from Mid-Atlantic hydrothermal vents. Biol. Bull. Mar. Biol. Lab. Woods Hole 196, 265-272.

MacDonald, I.R., Boland, G.S., Baker, J.S., Brooks, J.M., Kennicutt II, M.C., Bidigare, R.R., 1989. Gulf of Mexico hydrocarbon seep communities. 2. Spatial distribution of seep organisms and hydrocarbons at Bush Hill. Mar. Biol. 101, 235-247.

Marsh, A.G., Mullineaux, L.S., Young, C.M., Manahan, D.T., 2001. Larval dispersal potential of the tubeworm Riftia pachyptila at deep-sea hydrothermal vents. Nature 411, 77-80.

Mayer, L.A., Shor, A.N., Shor, A.N., Hughes Clarke, J., Piper, D.J.W., 1988. Dense biological communities at $3850 \mathrm{~m}$ on the Laurentian Fan and their relationship to the deposits of the 1929 Grand Banks earthquake. Deep-Sea Res. 35, 1235-1246.

Meredith, M.P., Garabato, A.C.N., Stevens, D.P., Heywood, K.J., Sanders, R.J., 2001. Deep and bottom waters in the eastern Scotia Sea: rapid changes in properties and circulation. J. Phys. Oceanogr. 31, 2157-2168.

Mullineaux, L.S., Kim, S.L., Pooley, A., Lutz, R.A., 1996. Identification of archaeogastropod larvae from a hydrothermal vent community. Mar. Biol. 124, 551-560.

Murray, J., Hjort, J., 1912. The Depths of the Ocean. MacMillan, London.

Murton, B.J., Klinkhammer, G., et al., 1993. Direct measurements of the distribution and occurrence of hydrothermal activity between $27^{\circ} \mathrm{N}$ and $37^{\circ} \mathrm{N}$ on the Mid-Atlantic Ridge. EOS Trans. Am. Geophys. Union $74,99$. 
Murton, B.J., Van Dover, C.L., Southward, E.C., 1995. Geological setting and ecology of the Broken Spur hydrothermal vent field: $29^{\circ} 10^{\prime} \mathrm{N}$ on the Mid-Atlantic Ridge. In: Parson, L.M., Walker, C.L., Dixon, D. (Eds.), Hydrothermal Vents and Processes. Geological Society of London, pp. 33-41.

Normark, W.R., Lupton, J.E., Murray, J.W., Koski, R.A., Clague, D.A., Morton, J.L., Delaney, J.R., Johnson, H.P., 1982. Polymetallic sulfide deposits and water-column tracers of active hydrothermal vents on the southern Juan de Fuca Ridge. Mar. Technol. Soc. J. 16, 46-52.

Normark, W.R., Morton, J.L., Koski, R.A., Clague, D.A., Delaney, J.R., 1983. Active hydrothermal vents and sulfide deposits on the southern Juan de Fuca Ridge. Geology 11, 158-163.

Ohta, S., Laubier, L., 1987. Deep biological communities in the subduction zone of Japan from bottom photographs taken during Nautile dives in the Kaiko project. Earth Planet. Sci. Lett. 83, 329-342.

Okutani, T., Egawa, K., 1985. The first underwater observation on living habit and thanatocoenoses of Calyptogena soyoae in bathyal depth of Sagami Bay. Venus Jpn. J. Malacol./Kaizatsu 44, 285-289.

Okutani, T., Metivier, B., 1986. Descriptions of three new species of vesicomyid bivalves collected by the submersible Nautile from abyssal depths off Honshu, Japan. Venus Jpn. J. Malacol./Kaizatsu 45, 147-160.

Olu, K., Duperret, A., Sibuet, M., Foucher, J.P., Fiala-Medioni, A., 1996. Structure and distribution of cold seep communities along the Peruvian active margin: relationship to geological and fluid patterns. Mar. Ecol. Progr. Ser. 132, 109-125.

Olu, K., Lance, S., Sibuet, M., Henry, P., Fiala-Medioni, A., Dinet, A., 1997. Cold seep communities as indicators of fluid expulsion patterns through mud volcanoes seaward of the Barbados accretionary prism. Deep-Sea Res. 44, 811-841.

Paull, C.K., Hecker, B., Commeau, R., Freeman-Lynde, R.P., Neumann, C., Corso, W.P., Golubic, S., Hook, J.E., Sikes, E., Curray, J., 1984. Biological communities at the Florida Escarpment resemble hydrothermal vent taxa. Science 226, 965-967.

Paull, C.K., Ussler III, W., Browski, W.S., Spiess, F.N., 1995. Methane-rich plumes on the Caroline continental rise: associations with gas hydrates. Geology 23, 89-92.

Peek, A.S., Gustafson, R.G., Lutz, R.A., Vrijenhoek, R.C., 1997. Evolutionary relationships of deep-sea hydrothermal vent and cold-water seep clams Bivalvia: Vesicomyidae: results from mitochondrial cytochrome oxidase subunit I. Mar. Biol. 130, 151-161.

Pradillon, F., Shillito, B., Young, C.M., Gaill, F., 2001. Developmental arrest in vent worm embryos. Nature 413, 698-699.

Ramirez-Llodra, E.Z., Tyler, P.A., Copley, J.T., 2000. Reproductive biology of three caridean shrimp, Rimicaris exoculata, Chorocaris chacei and Mirocaris fortunata Caridea: Decapoda, from hydrothermal vents. J. Mar. Biol. Assoc. UK 80, 473-484.

Renard, V., Hekinian, R., Francheteau, J., Ballard, R.D., Backer, H., 1985. Submersible observations at the axis of the ultra-fast spreading East Pacific Rise $17^{\circ} 30^{\prime}$ to $21^{\circ} 30^{\prime}$. S. Earth Planet. Sci. Lett. 75, 339-353.

Rona, P.A., Klinkhammer, G., Nelson, T.A., Trefry, J.H., Elderfield, H., 1986. Black smokers, massive sulphides and vent biota at the Mid-Atlantic Ridge. Nature 321, 33.

Rona, P.A., Deninger, R.P., Fisk, M.R., Howard, K.J., Klitgord, K.D., McClain, J.S., McMurray, G.R., Taghon, G.L., Wiltshire, J.C., 1990. Major off-axis hydrothermal activity on the northern Gorda Ridge. Geology 18, 493-496.

Rudnicki, M.D., German, C.R., Kirk, R.E., Sinha, M., Elderfield, H., Riches, S., 1995. New instrument platform tested at Mid-Atlantic Ridge. EOS Trans. Am. Geophys. Union 76, 329-330.

Scheirer, D.S., Baker, E.T., Johnson, K.T.M., 1998. Detection of hydrothermal plumes along the Southeast Indian Ridge near the Amsterdam-St. Paul Plateau. Geophys. Res. Lett. 25, 97-100.
Segonzac, M., 1992. Les peuplements associes a l'hydrothermalisme oceanique du Snake Pit dorsal medio-Atlantique: $23^{\circ}$ N, 3480 m: composition et microdistribution de la megafaune. C. R. Acad. Sci. Paris Ser. III 314, 593-600.

Shank, T.M., Fornari, D.J., Von Damm, K.L., Lilley, M.D., Haymon, R.M., Lutz, R.A., 1998. Temporal and spatial patterns of biological community development at nascent deep-sea hydrothermal vents $9^{\circ} 50^{\prime} \mathrm{N}$, East Pacific Rise. Deep-Sea Res. II 45, 465-515.

Sibuet, M., Olu, K., 1998. Biogeography, biodiversity and fluid dependence of deep-sea cold-seep communities at active and passive margins. Deep-Sea Res. II 45, 517-567.

Sibuet, M., Juniper, S.K., Pautot, G., 1988. Cold-seep benthic communities in the Japan subduction zones: geological control of community development. J. Mar. Res. 46, 333-348.

Sibuet, M., Fiala-Medioni, A., Foucher, J.P., Olu, K., 1990. Spatial distribution of clams colonies at the toe of the Nankai accretionary prism near $138^{\circ}$ E. International Conference on Fluids in Subduction Zones and Related Processes, Paris.

Simoneit, B.R.T., Lonsdale, P.F., Edmond, J.M., Shanks III, W.C., 1990. Deep-water hydrocarbon seeps in Guaymas Basin. Gulf of California. Appl. Geochem. 5, 41-49.

Southward, E.C., Tunnicliffe, V., Black, M.B., Dixon, D.R., Dixon, L.R.J., 1996. Ocean-ridge segmentation and vent tubeworms Vestimentifera in the NE Pacific. In: MacLeod, C.J., Tyler, P.A., Walker, C.L. (Eds.), Tectonic, Magmatic, Hydrothermal and Biological Segmentation of Mid-Ocean Ridges. Geological Society of London, pp. 211-234.

Spiess, R., MacDonald, K.C., Atawater, T., Ballard, R.D., Carranza, A., Cordoba, D., Cox, C., Diaz Garcia, V., Francheteau, J., Guerrero, J., Hawkins, J., Haymon, R.M., Hessler, R., Juteau, T., Kastner, M., Larson, R., Luyendyk, B., MacDougall, J., Miller, S., Normark, W.R., Orcutt, J., Rangin, C., 1980. East Pacific Rise: hot springs and geophysical experiments. Science 207, 1421-1433.

Statham, P.J., Connelly, D.P., German, C.R., Bulukin, E., Millard, N., McPhail, S., Pebody, M., Perrett, J., Squires, M., Stevenson, P., Webb, A. Mapping the 3D spatial distribution of dissolved manganese in coastal waters using an in situ analyser and the autonomous underwater vehicle Autosub. J. Soc. Underwater Technol. (in press).

Stuardo, J., Valdovinos, C., 1988. A new bathyal Calyptogena (Bivalvia: Vesicomyidae) from off the coast of central Chile. Venus Jpn. J. Malacol./Kaizatsu 47, 241-250.

Sudarikov, S.M., Galkin, S.V., 1995. Geochemistry of the Snake Pit vent field and its implications for vent and non-vent fauna. In: Parson, L.M., Walker, C.L., Dixon, D.R. (Eds.), Hydrothermal Vents and Processes. Geological Society of London, pp. 319-327.

Suess, E., Carson, B., Ritger, S.D., Moore, J.C., Jones, M.L., Kulm, L.D., Cochran, G.R., 1985. Biological communities at vent sites along the subduction zone off Oregon. Bull. Biol. Soc. Wash. 6, 475-484.

Suess, E., Bohrmann, G., von Huene, R., Linke, P., Wallman, K., Winckler, G., Lutz, R.A., Orange, D., 1998. Fluid venting in the Aleutian subduction zone. J. Geophys. Res. 103, 2597-2614.

Thiébaut, E., Huther, X., Shillito, B., Jollivet, D., Gaill, F., 2002. Spatial and temporal variations of recruitment in the tube worm Riftia pachyptila on the East Pacific Rise $\left(9^{\circ} 50 \mathrm{~N}\right.$ and $\left.13^{\circ} \mathrm{N}\right)$. Mar. Ecol. Progr. Ser. 234, 147-157.

Thurnherr, A.M., Richards, K.J., German, C.R., Lane-Serff, G.F., Speer, K.G., 2002. Flow and mixing in the rift valley of the Mid-Atlantic Ridge. J. Phys. Oceanogr. 132, 1763-1778.

Tunnicliffe, V., 1991. The biology of hydrothermal vents: ecology and evolution. Oceanogr. Mar. Biol. Annu. Rev. 29, 319-407.

Tunnicliffe, V., Juniper, S.K., de Burgh, M.E., 1985. The hydrothermal vent community of Axial seamount, Juan de Fuca Ridge. Bull. Biol. Soc. Wash. 6, 453-464.

Tunnicliffe, V., Botros, M., De Burgh, M.E., Dinet, A., Johnson, H.P., Juniper, S.K., McDuff, R.E., 1986. Hydrothermal vents of Explorer Ridge, Northeast Pacific. Deep-Sea Res. A 33, 401-412. 
Tunnicliffe, V., McArthur, A.G., McHugh, D., 1998. A biogeographical perspective of the deep-sea hydrothermal vent fauna. Adv. Mar. Biol. 34, 353-442.

Tyler, P.A., Dixon, D.R., 2000. Temperature/pressure tolerance of the first larval stage of Mirocaris fortunata from Lucky Strike hydrothermal vent field. J. Mar. Biol. Assoc. UK 80, 739-740.

Tyler, P.A., Young, C.M., 1999. Reproduction and dispersal at vents and cold seeps. J. Mar. Biol. Assoc. UK 79, 193-208.

Van Dover, C.L., 1995. Ecology of Mid-Atlantic hydrothermal vents. In: Parson, L.M., Walker, C.L., Dixon, D. (Eds.), Hydrothermal Vents and Processes. Geological Society of London, pp. 257-294.

Van Dover, C.L., 2000. The ecology of deep-sea hydrothermal vents. Princeton University Press, Princeton, NJ.

Van Dover, C.L., Hessler, R., 1990. Spatial variation in faunal composition of hydrothermal vent communities on the East Pacific Rise and Galapagos spreading centre. In: McMurray, G.R. (Ed.), Gorda Ridge: A Seafloor Spreading Centre in the United States' Exclusive Economic Zone. Springer-Verlag, New York, pp. 253-264.

Van Dover, C.L., Desbruyères, D., Segonzac, M., Comtet, T., Saldanha, L., Fiala-Medioni, A., Langmuir, C., 1996. Biology of Lucky Strike hydrothermal field. Deep-Sea Res 43, 1509-1529.

Van Dover, C.L., Humphris, S.E., Fornari, D., Cavanaugh, C.M., Collier, R., Goffredi, S.K., Hashimoto, J., Lilley, M.D., Reysenbach, A.L., Shank, T.M., Von Damm, K.L., Banta, A., Gallant, R.M.,
Vrijenhoek, R.C., et al., 2001. Biogeography and ecological setting of Indian Ocean hydrothermal vents. Science 294, 818-823.

Van Dover, C.L., German, C.R., Speer, K.G., Parson, L.M., Vrijenhoek, R.C., 2002. Evolution and biogeography of deep-sea vent and seep invertebrates. Science 295, 1253-1257.

Von Stackelberg, U., party, 1988. Active hydrothermalism in the Lau back-arc basin SW Pacific: first results from the SONNE 48 Cruise 1987. Mar. Mineral 7, 431-442.

Vrijenhoek, R.C., 1997. Gene flow and genetic diversity in naturally fragmented metapopulations of deep-sea hydrothermal vent animals. J. Hered. 88, 285-293.

Vrijenhoek, R.C., Schutz, S.J., Gustafson, R.G., Lutz, R.A., 1994. Cryptic species of deep-sea clams Mollusca: Bivalvia: Vesicomyidae from hydrothermal vent and cold-water seep environments. Deep-Sea Res. 41, 1171-1189.

Vrijenhoek, R.C., Shank, T., Lutz, R.A., 1998. Gene flow and dispersal in deep-sea hydrothermal vent animals. Cah. Biol. Mar. 39, 363-366.

Williams, A.B., Dobbs, F.C., 1995. A new genus and species of caridean shrimp Crustacea: Decapoda: Bresiliidae from hydrothermal vents on Loihi Seamount. Hawaii. Proc. Biol. Soc. Wash. 108, 228-237.

Young, C.M., Vazquez, E., Metaxas, A., Tyler, P.A., 1996. Embryology of vestimentiferan tube worms from deep-sea methane/sulphide seeps. Nature 381, 514-516. 